\title{
Lysosomal function in neurodegenerative diseases
}

\author{
Jianhua Zhang \\ From 2011 International Conference on Molecular Neurodegeneration \\ Shanghai, China. 22-24 September 2011
}

Protein aggregation, mitochondrial deficits, oxidative and autophagic stress are prominent pathologies in neurodegenerative diseases. Our laboratory has a long term interest in the regulation of autophagy-lysosomal activities in neurodegeneration. We previously found that deficiency in the lysosomal cathepsin D in a mouse knockout model led to accumulation of the key protein in Parkinson's disease, $\alpha$-synuclein. Overexpression of cathepsin D in human neuroblastoma cells as well as worms reduced $\alpha$-synuclein aggregation and toxicity. Recent work found that enhanced expression of lysosomal cathepsin D reduced both full-length and fragmented huntingtin in transfected HEK cells, and protected against mutant huntingtin toxicity in primary neurons. Furthermore, as mitochondria are the major generators and targets of reactive species, and oxidative stress has been found in a wide range of neurodegenerative diseases, investigating the source and nature of oxidative stress in cathepsin deficient brains are of significant interest. It has been previously shown that $\alpha$-synuclein modification by S-nitrosylation enhances its aggregation propensity. Furthermore, microglial produced nitrous oxide (NO) from an increase in inducible nitrous oxide synthase (iNOS) underlies some of the brain pathologies in CD knockout mice. Given that other lysosomal storage conditions have demonstrated mitochondrial involvement and that oxidative and nitrative changes have been associated with $\mathrm{CD}$ deficiency, we studied the effects of $\mathrm{CD}$ deficiency on mitochondrial morphology and function with the intent to understand how this lysosomal enzyme play a role in maintaining cellular bioenergetics and management of cellular oxidative states. We have found that although there are no changes in total mitochondrial biomass due to $\mathrm{CD}$ deficiency, there are enlarged mitochondria, and deficits in functional

Center for Free Radical Biology, Department of Pathology, University of Alabama at Birmingham, Birmingham VA Medical Center, Birmingham, AL 35294, USA

๑ 2012 Zhang; licensee BioMed Central Ltd. This is an Open Access article distributed under the terms of the Creative Commons Attribution License (http://creativecommons.org/licenses/by/2.0), which permits unrestricted use, distribution, and reproduction in any medium, provided the original work is properly cited. parameters of the electron transport chain. The changes demonstrated in this study contribute to the understanding of how mitochondrial/lysosomal interplay affects the pathogenesis of neurodegenerative diseases.

Published: 7 February 2012

doi:10.1186/1750-1326-7-S1-O2

Cite this article as: Zhang: Lysosomal function in neurodegenerative diseases. Molecular Neurodegeneration 2012 7(Suppl 1):O2.

Submit your next manuscript to BioMed Central and take full advantage of:

- Convenient online submission

- Thorough peer review

- No space constraints or color figure charges

- Immediate publication on acceptance

- Inclusion in PubMed, CAS, Scopus and Google Scholar

- Research which is freely available for redistribution Submit your manuscript at
www.biomedcentral.com/submit C BioMed Central 